\title{
Economic and Productivity Growth Decomposition:
}

\section{An Application to Post-reform China}

\author{
Kui-Wai Li ${ }^{a^{*}}$ and Tung Liu ${ }^{\mathrm{b}}$ \\ a Department of Economics and Finance, City University of Hong Kong, Hong Kong \\ ${ }^{\mathrm{b}}$ Department of Economics, Ball State University, USA
}

\begin{abstract}
This paper examines and applies the theoretical foundation of the decomposition of economic and productivity growth to the thirty provinces in China's post-reform economy. The four attributes of economic growth are input growth, adjusted scale effect, technical progress, and efficiency growth. A stochastic frontier model with a translog production and incorporated with human capital is used to estimate the growth attributes in China. The empirical results show that input growth is the major contributor to economic growth and human capital is inadequate even though it has a positive and significant effect on growth. Technical progress is the main contributor to productivity growth and the scale effect has become important in recent years. The impact of technical inefficiency is statistical insignificant in the sample period. The relevant policy implication for a sustainable post-reform China economy is the need to promote human capital accumulation and improvement in technical efficiency.
\end{abstract}

Keywords: technical progress, technical efficiency, returns to scale, human capital, China economy

JEL Classification: C2, D24, O4, O53

*Corresponding author: Tel.: 852-34428805; fax: 852-34420195

E-mail address: efkwli@cityu.edu.hk (Kui-Wai Li)

Acknowledgement: The authors would like to thank James Mirrlees, John Strauss, Belton Fleisher, Lee Spector, Wing Thye Woo and participants in the Conference on "China and the World Economy”, Nottingham University Ningbo Campus, China, November 6-7, 2008, and the Shanghai Forum, Fudan University, China, May 11-13, 2009, anonymous referees and Stephen G. Hall for their comments on the earlier draft of the paper, and Gilbert Lui, Lihong Yun, Liang Wang and Helen Lam for their research assistance. Financial supports for two Strategic Research Grants (project numbers 7001907 and 7002175) from City University of Hong Kong are gratefully acknowledged. The authors are solely responsible for any remaining errors. 


\section{Introduction}

In studying the technical change in the U.S., Solow (1957) differentiated the movements along the production function, which is caused by the input growth, from the shifts of the production function, which is defined as technical progress. With the assumption of constant returns to scale and perfect competition in the product market, the growth of output per unit of labor can be decomposed into technical progress and the weighted growth of capital per unit of labor. Technical progress has often been estimated by time series data of output and capital per unit of labor and the share of capital. Such a measure is referred to as "Solow residual." For a multiple inputs production function, the total factor productivity (TFP) growth is widely used as a measure of productivity change. While the classical approach in the TFP analysis often assumes optimality in production capacity, the output-oriented stochastic frontier production approach (Aigner et al., 1977) argues that, with given sets of factor inputs and due to possible technical inefficiency, there can be deviation between actual and optimal output. The measure of technical inefficiency can thus be added to the analysis of TFP growth by using the stochastic frontier model. ${ }^{1}$

There are at least three different ways to measure TFP growth: the index-number approach, the production function approach, and the cost function approach (Cowing and Stevenson, 1981; Denny et al., 1981; Bauer, 1990). The index-number approach has been used mostly in the early studies. The production function approach is more convenient than the cost function approach since it does not require any cost information. In spite of different measurement approaches, the TFP growth is composed of technical progress, technical efficiency change, and a scale economies effect (Bauer, 1990; Kumbhakar and Lovell, 2000). Technical progress refers to an outward shift of the production frontier due probably to greater use of technology and innovation that yields a larger production capacity. Technical efficiency change refers to an overall movement from a position within the production frontier towards the production frontier. The scale economies effect contributes to the output and productivity growth due to increasing returns to scale. With

\footnotetext{
${ }^{1}$ Both the data envelopment analysis (DEA) (Charnes et al., 1978) and the distance function approach (Fu, 2005; Brummer et al., 2006) are the alternative measures of technical efficiency, but due to their non-parametric and deterministic nature, the stochastic frontier analysis tends to be the more popular approach.
} 
increasing returns to scale in production, output increases at a higher percentage with respect to input increases and induces productivity improvement. ${ }^{2}$

This paper extends the production function approach in Solow's (1957) classical model and follows Denny et al., (1981), Bauer (1990), and Kumbhakar and Lovell (2000) to examine the theoretical foundation of the decomposition of economic and productivity growth. We relax the assumption of constant returns to scale and consider technical inefficiency in a stochastic frontier model. The output growth is then decomposed into: input growth, adjusted scale effect, technical progress, and efficiency growth. Furthermore, TFP growth is decomposed into: adjusted scale effect, technical progress, and efficiency growth (Kunbhakar and Lovell, 2000).

The empirical study on the post-reform China economy is based on the stochastic frontier model with a translog production function (Christensen et al., 1971) that incorporates a human capital variable. Although the production stochastic frontier analysis has been used in other studies on the Chinese economy, most studies have focused on one or two components of productivity growth, while technical progress and/or returns to scale have been absent (Kalirajan et al., 1996; Carter and Estrin, 2001; Hu and McAller, 2005; Tong, 1999; Dong and Putterman, 1997; Wu, 1995, 2000).

Lacking a distinct method of constructing China's physical and human capital stocks in recent studies (Bai et al., 2006; He et al., 2007; Funke and Yu, 2009; Perkins and Rawski, 2008; Qian and Smyth, 2006; Urel and Zebregs, 2009), this paper chooses to extend, revise and update the dataset and the methodology used in deriving the national and provincial physical capital and human capital stocks in Chow and Li (2002), Liu and Li (2006), Li (2003, 2009), and Li et al. (2009) and estimates the components of the economic and productivity growth for China's thirty provinces for the sample period of 1985-2006. China's national and provincial capital are approximated from investment figures (Chow, 1993), while a perpetual inventory approach adjusted by provincial migration and mortality rates is used in construction the human capital stock (Wang and Yao, 2003; Barro and Lee, 2001; Howitt, 2005).

Section 2 discusses the theoretic foundation of the decomposition of economic

\footnotetext{
2 The empirical study of this decomposition of the TFP growth has earlier been applied to Korea with the production function approach by Kim and Han (2001) and with the cost function approach by Kwack and Sun (2005), and to the U.S. with the production function approach by Sharma et al. (2007).
} 
and productivity growth, Section 3 elaborates on the data used for empirical estimation of the growth experience in post-reform China and introduces the empirical model. Section 4 presents the empirical results, while section 5 concludes the study.

\section{Decomposing Growth and Productivity}

Although classical economic growth models assume technical efficiency and production always occurs on the production frontier, the occurrence of technical inefficiency in a production function can be shown by using a stochastic frontier model (Aigner et al., 1977; Battese and Coelli, 1988 and 1992; Greene, 2005),

$$
Y_{t}=F\left(X_{1 t}, X_{2 t}, \cdots, X_{n t}, t\right) e^{-u_{t}},
$$

where $Y$ is the actual level of output; $F$ is the potential production function with $n$ inputs; $X_{i t}$ is $i^{\text {th }}$ input; and $u$ is a half-normally distributed random variable with a positive mean. The inclusion of $t$ in $F$ allows for the production function to shift over time due to technical progress. The last term $e^{-u_{t}}$ measures technical inefficiency. Taking logarithm transformation yields

$$
\log Y_{t}=\log F\left(X_{1 t}, X_{2 t}, \cdots, X_{n t}, t\right)-u_{t} .
$$

Technical inefficiency occurs when $u_{t}>0$ and the level of $\log Y_{t}$ is less than the level of $\log F$. Differentiating Equation (2) with respect to time yields the following output growth equation:

$$
\dot{Y}_{t}=\sum_{i} \frac{\partial F}{\partial X_{i t}} \frac{X_{i t}}{F} \dot{X}_{i t}+\frac{\partial F / \partial t}{F}-\frac{\partial u_{t}}{\partial t}
$$

where $\dot{Y}_{t}=\frac{\partial Y_{t} / \partial t}{Y_{t}}$ is the growth of output and $\dot{X}_{i t}=\frac{\partial X_{i t} / \partial t}{X_{i t}}$ is the growth of input $X_{i t}$.

Define $e_{i t}=\frac{\partial F}{\partial X_{i t}} \frac{X_{i t}}{F}$ as the output elasticity for input $X_{i t}$. Let $e_{t}=\sum_{i} e_{i t}$ (the sum of the elasticity to each input). It can be shown that $e_{t}$ is a measure of returns to scale. Suppose changes in all inputs have the same scale, $\Delta X_{i t}=a X_{i t}$. Consider the changes in output $\Delta F$ by taking the total derivative of $F\left(X_{1}, X_{2}, \cdots, X_{n}, t\right)$ and substituting 
$\Delta X_{i t}=a X_{i t}$ into $\Delta F$, we have

$$
\begin{aligned}
\Delta F & =\sum_{i} \frac{\partial F}{\partial X_{i t}} \Delta X_{i t}+\frac{\partial F}{\partial t} \Delta t=F \sum_{i} \frac{\partial F}{\partial X_{i t}} \frac{a X_{i t}}{F}+F \dot{A}_{t}=F a \sum_{i} e_{i t}+F \dot{A}_{t} \\
& =a F e_{t}+F \dot{A}_{t},
\end{aligned}
$$

where $\dot{A}_{t}=\frac{\partial F / \partial t}{F}$ is technical progress. The production shows increasing (constant, decreasing) returns to scale when $e_{t}>1(=1,<1)$.

Define the technical efficiency $(T E)$ as the ratio of the actual output and the potential output, $T E_{t}=\frac{Y}{F}=e^{-u_{t}}$. Then, the growth of the technical efficiency $T \dot{E}_{t}$ is

$$
T \dot{E}_{t}=-\frac{\partial u_{t}}{\partial t}
$$

The output growth can be represented as

$$
\dot{Y}_{t}=\sum_{i} e_{i t} \dot{X}_{i t}+\dot{A}_{t}+T \dot{E}_{t}
$$

Consider the following cost minimization problem under perfect competition in the factors markets, but not necessary in the product market.

$$
\min _{X_{i t}} C_{t}=\sum_{i} w_{i t} X_{i t} \text { subject to } Y_{t}=F\left(X_{1 t}, X_{2 t}, \cdots, X_{n t}, t\right) e^{-u_{t}} \text {. }
$$

We express the objective function and the constraint in the Lagrangian form.

$$
L\left(X_{i t}, \lambda\right)=\sum_{i} w_{i t} X_{i t}+\lambda\left(Y_{t}-F e^{-u_{t}}\right),
$$

where $\lambda$ is the Lagrange multiplier. The first-order condition for minimization is

$$
w_{i t}=\lambda \frac{\partial F}{\partial X_{i t}} e^{-u_{t}}
$$

Or,

$$
w_{i t}=\lambda \frac{\partial F}{\partial X_{i t}} e^{-u_{t}}=\lambda \frac{\partial F}{\partial X_{i t}} \frac{X_{i t}}{F} \frac{F}{X_{i t}} e^{-u_{t}}=\lambda e_{i t} \frac{Y_{t}}{X_{i t}} .
$$

Multiplying both sides by $X_{i t}$,

$$
w_{i t} X_{i t}=\lambda e_{i t} Y_{t} \text {. }
$$

Taking the sum of all inputs, the total cost is 


$$
\sum_{i} w_{i t} X_{i t}=\sum_{i} \lambda e_{i t} Y_{t}
$$

Or,

$$
C_{t}=\lambda e_{t} Y_{t}
$$

Denote the cost share of input $X_{i t}$ as $s_{i t}$. Dividing Equation (11) by Equation (13), the cost share is

$$
s_{i t}=\frac{w_{i t} X_{i t}}{C_{t}}=\frac{e_{i t}}{e_{t}} .
$$

This shows that the cost share is always equal to the relative output elasticity in the case of cost minimization. ${ }^{3}$ We can rewrite the output growth Equation (6) as

$$
\dot{Y}_{t}=e_{t} \sum_{i} \frac{e_{i t}}{e_{t}} \dot{X}_{i t}+\dot{A}_{t}+T \dot{E}_{t}
$$

By adding and subtracting term,

$$
\dot{Y}_{t}=\sum_{i} \frac{e_{i t}}{e_{t}} \dot{X}_{i t}+\left(e_{t}-1\right) \sum_{i} \frac{e_{i t}}{e_{t}} \dot{X}_{i t}+\dot{A}_{t}+T \dot{E}_{t}
$$

Using Equation (14),

$$
\dot{Y}_{t}=\sum_{i} s_{i t} \dot{X}_{i t}+\left(e_{t}-1\right) \sum_{i} s_{i t} \dot{X}_{i t}+\dot{A}_{t}+T \dot{E}_{t}
$$

Equation (16) shows the decomposition without cost information (w) and can be used for the empirical estimation of the sources of output growth, if the parameters of the production function are known. Equation (17) shows that output growth can be decomposed into four components: weighted sum of input growth, adjusted scale effect, technical progress, and growth of technical efficiency. For the first term in Equation (17), the weight for each input growth is equal to the cost share of each input. The second term represents the adjusted scale effect. When the returns to scale are constant, this term is zero. For the production with increasing returns to scale, $e_{t}>1$, a part of returns to scale $\left(e_{t}-1\right)$ contributes to the output growth if aggregate input growth is positive. The contribution from returns to scale $\left(e_{t}-1\right)$ is weighted by the aggregate input growth $\sum_{i} s_{i t} \dot{X}_{i t}$. If the aggregate input growth is zero, then the scale effect is zero. The first two

\footnotetext{
3 Kumbhakar and Lovell (2000) include the allocative inefficiency component in the decomposition. Equation (14) shows that the allocative inefficiency does not exist when the cost minimization is used.
} 
terms in Equation (17) show that input growth has two impacts on output growth. One is the direct impact through its growth and the other is the indirect impact through scale effect.

The decomposition in Equations (16) and (17) has relaxed a major assumption in Solow's (1957) decomposition of economic growth, as Equation (17) does not require the constant returns to scale assumption. Indeed, the growth decomposition as shown by Equations (16) and (17) can be applied to any types of production function as long as output elasticity for each input can be derived. This implies that a nonlinear production function such as the translog function can be used for growth decomposition analysis.

Total factor productivity (TFP) can be defined as

$$
\operatorname{TFP}_{t}=\frac{Y_{t}}{\Phi_{t}},
$$

where $\Phi$ is the aggregate input. Taking logarithm and differentiation with respect to time, the TFP growth is

$$
\dot{T F P}_{t}=\dot{Y}_{t}-\dot{\Phi}_{t}
$$

Although it is not feasible to measure $\Phi$ since it is the aggregate of different inputs with different unit of measurements, a commonly used measure of input growth is the Divisia index (Jorgenson and Griliches, 1967).

$$
\dot{\Phi}_{t}=\sum_{i} \frac{w_{i t} X_{i t}}{C_{t}} \dot{X}_{i t}=\sum_{i} s_{i t} \dot{X}_{i t} .
$$

Substituting Equations (17) and (20) into (19), the TFP growth is

$$
T \dot{F} P_{t}=\left(e_{t}-1\right) \sum_{i} s_{i t} \dot{X}_{i t}+\dot{A}_{t}+T \dot{E}_{t} .
$$

Then, the TFP growth has three components: adjusted scale effect, technical progress, and growth of technical efficiency (Bauer, 1990; Kumbhakar and Lovell, 2000, pp. 284). ${ }^{4}$

\footnotetext{
${ }^{4}$ When production is constant returns to scale, $e_{t}=1$, and without technical inefficiency, the decomposition is reduced to $\dot{T F P}=\dot{A}$ as in Solow (1957).
} 


\section{Post-reform China and Estimation Method}

Despite the persistent high growth China experienced since economic reform in 1978, the reliability and accuracy of China's output data has been questioned in two separate debates. The debate on the inclusion of measurement factors (Young, 2000, 2003; Rawski and Xiao, 2001; Holz, 2004, 2006; Chow, 2006) concentrates on the estimation of the capital stock series, and that such detailed measures as the scrap rate and depreciation rate of the same capital equipment at different years are absent. Most studies ended up using adjusted China's output data that eventually are based on different sources of China data (e.g. Hsueh and Li, 1999). By concluding that the estimation of China's physical capital stock based on different assumptions does not vary much and the various capital stock series can be used as estimates to represent an acceptable scenario for empirical analysis, Holz (2006) must have realized that scrap rates and depreciation rates are assumed in empirical studies. Indeed, an OECD (2001) study argues that the more relevant contribution of a capital asset is the flow of capital services provided by the asset.

The other debate concerns the transformation from the Soviet material product system (MPS) to the system of national accounts (SNA) as the former does not value "non-market" and "non-materials" output and services and the deficiencies in China's national account and statistical practices (Maddison and Wu, 2008; Wu, 2000, 2003). There has been contrasting debate on whether China's national account has been over-estimated or under-estimated. The advocates based on the institutional effect argue that there are strong incentives for enterprises to oblige their supervising bureau by over-reporting output growth (Wu, 2000). In December 2004, China’s National Bureau of Statistics (NBS) reported that by incorporating non-agricultural activities, annual GDP estimates have been under-reported (Wu, 2007). China’s GDP has been revised upwards by US $\$ 300$ billion in December $2005 .^{5}$

Chow and Li (2002), Li (2003) and Chow (2006) argue that statistical deficiencies may cancel out each other if studies are based on time series rather than discrete analysis. It can be argued that while deficiencies in China's statistical reporting are improving slowly, there are additional problems as rapid economic transformation is occurring. For

\footnotetext{
${ }^{5}$ South China Morning Post, December 13 and 21, 2005, and January 13, 2006.
} 
example, economic formalization would mean that output from previously informal activities would now be reported in formal economic statistics and output would have gone up. The pace of economic development itself could have influenced the accuracy of output reporting.

Recent empirical studies have examined various dimensions and sources of economic growth and productivity change in China using adjusted data (Lin, 2000; Wang and Yao, 2003; Fleisher et al., 2010; Woo, 2002, 2006; Bosworth and Collins, 2008; Zhang, 2003; Islam et al., 2006). In particular, studies have used physical capital constructed from investment data to examine growth and productivity. Chow and $\mathrm{Li}$ (2002) and Li (2003) constructed the national and provincial capital stock data using different investment sources to estimate productivity change in China, while Liu and $\mathrm{Li}$ (2006) and $\mathrm{Li}$ (2009) further extended the analysis on growth and productivity to incorporate the human capital variable and provincial performances.

The data for China's thirty provinces used in this paper comes mainly from the latest issue of the Statistical Yearbook of China, the Comprehensive Statistical Data and Materials in 50 Years of New China (1999), and the two Chinese censuses of 1990 and 2000. The estimation on the production function requires an indicator for the physical capital stock approximated from investment figures (e.g. Young, 2003; Wu, 2000). We have followed the methodology and updated the capital stock used in Chow and $\mathrm{Li}$ (2002), Li (2003) and Liu and Li (2006) to 2006.

Human capital is generally related to the level of education, though empirically, a number of indicators are used as proxy for human capital (Barro and Lee, 1993, 1996 and 2001; Benhabib and Spiegel, 2005; Gemmell, 1996). ${ }^{6}$ Various assumptions and proxies have been used in constructing China's human capital stock (Young 2003; Wang and Yao 2003). Liu and $\mathrm{Li}$ (2006) and $\mathrm{Li}$ et al. (2009) have discussed China's post-reform education performance and constructed China's human capital stock using a perpetual inventory approach (Barro and Lee, 1993, 1996 and 2001). The initial human capital is derived from using the data in the two Population Censuses of 1990 and 2000. The annual graduates of the six schooling levels (Higher Education with 14.5 years,

\footnotetext{
${ }^{6}$ These indicators include (1) total years of schooling derived from educational enrolment ratios; (2) international test scores; and (3) numbers of workers pass through primary, secondary and tertiary education.
} 
Specialized Secondary, Vocational Secondary and Senior Secondary with 11 years, Junior Secondary with 8 years and Primary Education with 5 years) and the total numbers of persons that have attained various schooling levels within the age 15 - 64 years in 1990 are used as the benchmark. Data on the annual graduates in each schooling level are adjusted by the mortality rate and inter-provincial migration figures. ${ }^{7}$

The empirical estimation involves the panel data estimation with thirty provinces in China for the sample period from 1985 to 2006. The output for the production function is the provincial real GDP $(Y)$ and the inputs are labor $(L)$ indicated by the number of employed workers, physical capital $(K)$, and human capital $(H)$. The estimation model is the production with a second-order transcendental logarithmic (translog) form.

$$
\begin{aligned}
\ln Y_{i t}= & \alpha+\beta_{K} \ln K_{i t}+\beta_{L} \ln L_{i t}+\beta_{H} \ln H_{i t}+\beta_{K K}\left(\ln K_{i t}\right)^{2}+\beta_{L L}\left(\ln L_{i t}\right)^{2}+ \\
& \beta_{H H}\left(\ln H_{i t}\right)^{2}+\beta_{K L} \ln K_{i t} \ln L_{i t}+\beta_{K H} \ln K_{i t} \ln H_{i t}+\beta_{L H} \ln L_{i t} \ln H_{i t}+ \\
& \sum_{t=1986}^{2006} \delta_{T t} D T_{t}+\sum_{r} \delta_{R r} D R_{r}+v_{i t}-u_{i t},
\end{aligned}
$$

where the subscript $i$ is the $i$ th province and $t$ is the time period; $D T_{t}$ is the dummy variable for different years to capture technology change; $D R_{r}$ is the dummy variable for different regions that captures the region-specific effects; $H_{i t}$ is the human capital variable expressed in average schooling years. ${ }^{8}$ The parameter $\delta_{T t}$ can be used to measure technical level over time. The technical progress or the rate of change in technical level is $\delta_{T t}-\delta_{T t-1}$. The random error $v_{i t}$ is symmetric and normally distributed with $v_{i t} \sim N\left(0, \sigma_{v}^{2}\right)$ and $u_{i t}$ is a non-negative truncated normal random error with the probability distribution of $N\left(\mu, \sigma_{u}^{2}\right)$, where $\mu$ is the mode of normal distribution. The non-negative property of the random error $u_{i t}$ is used to measure technical inefficiency as in Equation (5). Technical inefficiency can either be time variant $\left(u_{i t}\right)$ or time invariant

\footnotetext{
7 The statistics on the number of graduates at Specialized Secondary and Vocational Secondary education levels are not available since 2004. The human capital data adjustment can be found in $\mathrm{Li}$ (2009).

${ }^{8}$ To control for the possible endogeneity of human capital, Liu and Li (2006) applied the two lags of human capital as instruments. Due to the complexity of the stochastic frontier model, this paper compromises the possible endogeneity of human capital, and focuses on output elasticity of the respective input variables and technical efficiency. If endogeneity is serious, the estimated coefficients will be biased and the conclusion from this paper may be conservative.
} 
$\left(u_{i}\right)$. In the case of time variant technical inefficiency, $u_{i t}$ can be expressed as a monotonic ‘decay' function as (Battese and Coelli, 1992, 1997):

$$
u_{i t}=\eta_{t} u_{i}
$$

where $\eta_{t}=\exp [-\eta(t-T)]$, and $\eta$ is an unknown scalar parameter. The technical inefficiency $u_{i t}$ can either be increasing (if $\eta<0$ ), decreasing (if $\eta>0$ ) or remained constant (if $\eta=0$ ).

From Equation (22), the output elasticity for physical capital, labor, and human capital for province $i$ and time $t$, which are denoted as $e_{K_{i t}}, e_{L_{i t}}$, and $e_{H_{i t}}$, respectively, can be derived as follows:

$$
\begin{aligned}
& e_{K_{i t}}=\beta_{K}+2 \beta_{K K} \ln K_{i t}+\beta_{K L} \ln L_{i t}+\beta_{K H} \ln H_{i t}, \\
& e_{L_{i t}}=\beta_{L}+2 \beta_{L L} \ln L_{i t}+\beta_{K L} \ln K_{i t}+\beta_{L H} \ln H_{i t}, \\
& e_{H_{i t}}=\beta_{H}+2 \beta_{H H} \ln H_{i t}+\beta_{K H} \ln K_{i t}+\beta_{L H} \ln L_{i t} .
\end{aligned}
$$

The returns to scale is measured as $e_{i t}=e_{K_{i t}}+e_{L_{i t}}+e_{H_{i t}}$. The cost shares of inputs are $s_{K_{i t}}=\frac{e_{K_{i t}}}{e_{i t}}, \quad s_{L_{i t}}=\frac{e_{L_{i t}}}{e_{i t}}$, and $s_{H_{i t}}=\frac{e_{H_{i t}}}{e_{i t}}$. Using Equations (17) and (21), the decomposition of output growth and the TFP growth is shown as follows:

$$
\begin{aligned}
& \dot{Y}_{i t}=s_{K_{i t}} \dot{K}_{i t}+s_{L_{i t}} \dot{L}_{i t}+s_{H_{i t}} \dot{H}_{i t}+\text { Scale }_{i t}+\Delta \delta_{T t}+T \dot{E}_{i t}, \\
& T \dot{F} P_{i t}=\text { Scale }_{i t}+\Delta \delta_{T t}+T \dot{E}_{i t},
\end{aligned}
$$

where Scale $_{i t}=\left(e_{i t}-1\right)\left(s_{K_{i t}} \dot{K}_{i t}+s_{L_{i t}} \dot{L}_{i t}+s_{H_{i t}} \dot{H}_{i t}\right)$ is a measure of the adjusted scale effect. From Equations (5) and (23), the growth of technical efficiency is

$$
T \dot{E}_{i t}=u_{i} \eta \exp (-\eta(t-T)) \text {. }
$$

The maximum likelihood method is generally used to estimate the parameters in a stochastic frontier production (Battese and Coelli, 1988 and 1992; Kumbhakar and Lovell, 2000; Kumbkakar, 1990). After estimating the parameters in Equation (22), Equations (24) - (26) are used for the calculation of output elasticities and the adjusted scale effect; the estimated coefficient for $\delta_{T t}$ gives the estimates of the technical progress. An estimator for $u_{i}$ can be obtained from $E\left(u_{i} /\left(\varepsilon_{i t}\right)\right)$, where $\varepsilon_{i t}=v_{i t}-u_{i t}$ and Equation (29) is then used to derive the estimate of the growth of technical efficiency. Equations 
(27) and (28) give the decomposition of economic growth and the TFP growth.

\section{Empirical Results}

Table 1 reports the maximum likelihood estimates of the stochastic frontier production for a panel of thirty provinces of China for the sample period of 1985-2006, giving a total of 644 observations. ${ }^{9}$ The dependent variable is log real GDP. Columns (1) and (2) show the results from the Cobb-Douglas production model, while columns (3) and (4) show the results from the translog specification of the production function. The difference between columns (1) and (2) and between columns (3) and (4) is the inclusion of regional dummy variables in columns (1) and (3). ${ }^{10}$

The last three rows in Table 1 show the three sets of model specification tests. The first set contains the likelihood ratio tests for the joint effects of quadratic and interaction terms in the translog specifications. The statistics shown in columns (3) and (4) are statistically significant. Therefore, the translog functional form is appropriate for the production function. The second set contains the likelihood test for the joint effect of time dummy variables. All statistics in this row show that the joint effect of time dummy variables is significant. The third set contains the likelihood ratio tests for the joint effects of regional dummy variables. The results in columns (2) and (4) show these tests are statistically significant. In sum, the translog specification function with regional dummy variables shown in column (4) represents a preferred model for further analysis.

Based on the model selection criterions AIC and BIC, the models in column (3) and column (4) are better than the other two models. The results in column (3) show that the estimated technical inefficiency parameter, $\eta$, is negative and statistically significant,

\footnotetext{
${ }^{9}$ A total of sixteen data values are missing in estimation due to missing human capital data in several provinces and years.

${ }^{10}$ The four sub-regions in China are chosen to reflect the geographical strength and economic concentration. The South region comprises nine southern provinces, commonly known as the Pearl River Delta region of Fujian, Guangdong, Guangxi, Hainan, Jiangxi, Hunan, Sichuan (including Chongqing), Guizhou and Yunnan. The East region consists of twelve provinces, including mainly provinces in the Yellow River and Yangtze River Delta regions of Beijing, Tianjin, Hebei, Shanghai, Jiangsu, Zhejiang, Shandong, Anhui, Henan, Hubei, Shanxi and Gansu. The West region refers to the remote provinces of Mongolia, Tibet, Shaanxi, Qinghai, Ningxia, and Xinjiang. The remaining three provinces in the North East region are Jilin, Heilongjiang and Liaoning, which consist of the traditional state-owned heavy industries.
} 
which indicates that the overall inefficiency is increasing over time. When the regional dummy variables are included, the results in column (4) show that the intercept for the South region is not significantly different from that of the East region; both Northeast and West regions have a lower and significant intercept. However, the estimate of technical inefficiency is negative, but insignificant. There is thus no strong statistical evidence to show that technical efficiency is declining over time once the regional dummy variables are included in estimation.

Based on the translog production function estimates shown in column (4) and Equations (24) - (29), we derive the following measures: the output elasticity with respect to factor inputs $\left(e_{K}, e_{L}, e_{H}\right)$, returns to scale $(e)$, the adjusted scale effect, rate of technical progress $\left(\Delta \delta_{T t}\right)$, and growth of technical efficiency $(T \dot{E})$. These measures are then used to derive the components of output growth and total factor productivity growth $(T \dot{F P})$. Because the translog specification is used, the performance of these measures varies depending on provinces and years.

Table 2 shows the averages of the output elasticities and cost shares for inputs of the provinces in different years. China's output elasticity for physical capital input shows an increasing trend starting from 0.543 in 1985 with an average of 0.614 in the sample period. Labor has an output elasticity that ranges between 0.278 and 0.337 with a mild declining trend. Human capital has the lowest value of output elasticity that ranges between 0.145 and 0.240 . The elasticity reaches the highest level in the last three years in the sample period. The large and steady increasing output elasticity for physical capital shows that physical capital is dominant in production and its dominance is increasing over time. By taking the sum of three output elasticities gives the values of returns to scale between 1.041 and 1.191. This gives slight evidence of increasing returns to scale $(e>1)$ and an increasing trend. The cost shares of inputs in the last three columns show that the cost share for physical capital is the highest with 56 percent on average; the share for labor is 28 percent while the share for human capital is only 16 percent.

Table 3 shows the estimates of weighted input growth for the three inputs and adjusted scale effects. The growth of aggregate input, the column under $\dot{\Phi}$, has an average of 6.409 percent. Physical capital accounts for 88 percent (5.631\% out of 6.409\%) 
of input growth while labor and human capital accounts for 7.32 percent and 4.5 percent, respectively. This implies that physical capital is the most important factor for input growth. The average physical capital growth in the sample period is 10 percent while the growth of labor and human capital are 1.67 percent and 1.87 percent, respectively (not shown in the table). Since the returns to scale shown in Table 2 are greater than one, this gives a positive scale effect $(e-1)$. Table 3 shows an increasing trend of $e-1$. The last column shows an increasing trend of the adjusted scale effect. The increase in the returns to scale and the input growth explains the increasing trend in the adjusted scale effect from 0.321 percent to 1.575 percent, with an average of 0.597 percent.

The decomposition of output growth and the TFP growth is shown in Table 4. For the four sources of the output growth, columns (2) - (5) show that: the major contributor to the economic growth is input growth, while both the adjusted scale effect (Scale) and technical progress $\left(\Delta \delta_{T t}\right)$ are positive, but the contribution from technical efficiency is negative in all years. On average, the input growth accounts for 63 percent of output growth (6.409\% out of $10.153 \%)$. Although the scale effect is positive and increases significantly over the sample period, its estimates are still about one-third to one-half of the estimates of technical progress for the last three years in our sample. The estimates of technical progress are all positive, except in 1989, and the estimates reached the highest level between 1992 and 1994 with values of 7.606, 5.970 and 5.114. The growths of technical efficiency are all negative in all years. However, the magnitude is small with an average of -0.095 percent. Based on the test statistic in Table 1, this negative impact should be statistical insignificant and negligible.

The estimates in Table 4 also show the impacts from Asian Financial Crisis in 1997-1998. China output growth started to decline in 1998 and recovered to before-the-crisis level in 2002. This decline in output growth due to Asian Financial Crisis can also be seen by the decline in input growth and adjusted scale effect between 1999 and 2001. Based on the estimates of the time dummy variables, it seems that the major reason for the decline of growth was caused by the sharp decline of technical progress from 3.201 percent in 1997 to 1.608 percent in 1998 . However, the time dummy variable is a proxy for the technical progress. Any significant event affecting the time dummy variables also appears as technical change. Because of the significance of Asian 
Financial Crisis in 1997-1998, the decline of the coefficient of time dummy variables should be considered as a result from a special event rather than fundamental technical changes.

In the decomposition of the TFP growth shown in columns (3) - (5), the overall mean of the TFP growth is 3.744 percent, which is close to other earlier studies (Borenstein and Ostry, 1996; Chow and Li, 2002; Li, 2003). The two major components are the scale effect (16\%) and technical change (86\%). The adjusted scale effect accounts for at least 20 percent of the TFP growth during the last three years in our sample period. The effect of the growth in technical inefficiency is small and negligible. These findings show that although factor accumulation may lead to the TFP growth through increasing returns to scale, the most important factor for China's growth in TFP is technical progress.

\section{Conclusions}

This paper examines and applies the theoretic foundation of the decomposition of economic and productivity growth to China's post-reform economy. Our theoretic discussion follows that of Solow (1957), Denny et al. (1981), Bauer (1990), and Kumbhakar and Lovell (2000) and shows that cost information is not required in estimating the components of decomposition and the production function approach is sufficient for the empirical work. The economic growth is decomposed into input growth, adjusted scale effect, technical progress, and growth in technical efficiency. With this decomposition, the TFP growth simply contains the last three components. The growth of aggregate input is the weighted sum of each input growth and the weight is the cost share of each input. The adjusted scale effect depends on the size of returns to scale. This effect is zero for constant returns to scale, but is adjusted by the aggregate input growth for increasing and decreasing returns to scale. Technical progress in the decomposition represents the shift of the production function over time. The technical efficiency can be measured and derived from stochastic frontier model.

For our empirical work on the production function, we have derived the physical and human capital stocks data using the inventory method for the thirty provinces of 
China for the period 1984-2006. The average number of schooling years is used as the proxy for the human capital stock, where the numbers of graduates, provincial immigration and mortality at various education levels are taken into account. We have updated and extended the TFP analysis in Chow and $\mathrm{Li}$ (2002), $\mathrm{Li}$ (2003) and Liu and $\mathrm{Li}$ (2006) with stochastic frontier analysis.

We estimate the stochastic frontier translog production function using the maximum-likelihood estimation method. Our empirical results show that the three factor inputs (physical capital, labor and human capital) are important for output performance. Among the three inputs, physical capital is the most important factor in China's post-reform economic growth. This conclusion is consistent with earlier studies (Galor and Moav, 2003; Goldin and Katz, 1998, 1999 and 2001). The role of human capital will become significant in the more mature stage of economic development, and it is important for China to upgrade its human capital for sustainable economic development.

When the three sources of the growth of TFP are considered, we found that the major contributor to the TFP growth is technology progress. The contribution from adjusted scale effect is increasing in our sample period. The empirical results do bring forward several policy implications on the sustainability of the post-reform China economy. It is necessary for China to promote investments that are more productive, especially those embodied with technology. Policies should be geared to improve technical efficiency and utilize resources effectively. While labor is plentiful, developed human capital is scarce in China. It will take a relatively long time for individuals to be educated and trained. Thus, continuous investment in education and training is necessary. Mobility of human capital can facilitate knowledge spillovers across different provinces in China, and encouraging international in-flows of talents might also be necessary. It will be interesting for future analysis, for example, to consider the efficiency level among industries in different regions in the post-reform China. 


\section{References}

Aigner, D., Lovell, K. and Schmidt, K. P. (1977), 'Formulation and estimation of stochastic frontier function models’, Journal of Econometrics, 6, 21-37.

Bai, C-E., Hsieh, C-T. and Qian, Y. (2006), 'The return to capital in China', Brooking Papers of Economic Activity, 37 (2), 61-102.

Barro, R. J. and Lee, J.-W. (1993), 'International comparisons of educational attainment', Journal of Monetary Economics, 32, 363-394.

Barro, R. J. and Lee, J.-W. (1996), 'International measures of schooling years and schooling quality', American Economic Review, 32, 363-394.

Barro, R. J. and Lee, J.-W. (2001), 'International data on educational attainment: updates and implications', Oxford Economics Paper, 3, 541-563.

Battese, G. E. and Coelli, T. J. (1988), 'Prediction of firm-level technical efficiencies with a generalised frontier production function and panel data', Journal of Econometrics, 38, 387-399.

Battese, G. E. and Coelli, T. J. (1992 ), 'Frontier production functions, technical efficiency and panel data: with application to paddy farmers in India', Journal of Productivity Analysis, 3(1), 153-169.

Bauer, P. W., 1990, 'Decomposing TFP growth in the presence of cost inefficiency, non-constant returns to scale, and technological progress, Journal of Productivity Analysis, 1, 287-299.

Benhabib, J. and Spiegel, M. M. (2005), 'Human capital and technology diffusion' in Handbook of Economic Growth, Aghion, P. and Durlauf, S. (eds), North-Holland: Elsevier.

Borensztein, E., and Ostry, D. J. (1996), ‘Accounting for China’s economic performance’, American Economic Review, 86, 224-228.

Bosworth, E. and Collins, S. M. (2008), 'Accounting for growth: comparing China and India', Journal of Economic Perspectives, 22 (1) Winter, 45-66.

Brummer, B., Clauben, T. and Lu, W. (2006), 'Policy reform and productivity change in Chinese agriculture: a distance function approach', Journal of Development Economics, 81, 61-79.

Carter, C.A. and Estrin, A. J. (2001), 'Market reforms versus structural reforms in rural China', Journal of Comparative Economics, 29, 527- 541.

Charnes, A., Cooper, W. W. and Rhodes, E. (1978), 'Measuring the efficiency of decision-making units', European Journal of Operational Research, 2 (6), 429-44.

China Statistical Yearbook (various issues), State Statistical Bureau, China Statistical Publishing House, Beijing.

Chow, G. C. (1993), 'Capital formation and economic growth in China', Quarterly Journal of Economics, 58, 809-842.

Chow, G. C. (2006), 'New capital estimates for China: comments', China Economic Review, 17 (2): 186-192.

Chow, G. C. and Li, K.-W. (2002), 'China’s economic growth: 1952-2010', Economic Development and Cultural Change, 51 October, 247-256.

Christensen, L. R., Jorgenson, D. W. and Lau, L. J. (1971), 'Conjugate duality and the transcendental logarithmic production function,' Econometrica, 39, 255-56.

Comprehensive Statistical Data and Materials on 50 Years of New China (1999), 
Department of Comprehensive Statistics of National Bureau of Statistics, China Statistics Press, Beijing.

Cowing, T. G. and Stevenson, R. E. (1981), Productivity Measurement in Regulated Industries, New York: Academic Press.

Denny, M., Fuss, M. and Waverman, L. (1981), 'The measurement and interpretation of total factor productivity in regulated industries with an application to Canadian telecommunications' in T. G. Cowing and R. E. Stevenson (eds.), Productivity Measurement in Regulated Industries, New York: Academic Press, pp. 179- 218.

Dong, X.-Y. and Putterman, L. (1997), 'Productivity and organization in China's rural industries: a stochastic frontier analysis', Journal of Comparative Economics, 24, 181-201.

Fleisher, B., Li, H. and Zhao, M. Q. (2010), 'Human capital, economic growth, and regional inequality in China', Journal of Development Economics, 92, 215-231.

Fu, Xiaolan, (2005), 'Exports, technical progress and productivity growth in a transition economy: a non-parametric approach for China', Applied Economics, 37, 725-739.

Funke, Michael and Yu, H. (2009), Economic Growth across Chinese Provinces: In Search of Innovation-Driven Gains, Discussion Paper, Institute for Economies in Transition, Bank of Finland, Helsinki, October.

Galor, O. and Moav, O. (2003), Das Human Kapital: A Theory of the Demise of the Class Structure, Brown University.

Gemmell, N. (1996), 'Evaluating the impacts of human capital stocks and accumulation on economic growth: some new evidence', Oxford Bulletin of Economics and Statistics, 58, 9-28.

Goldin, C. and Katz, L. F. (1998), 'The origins of technology-skill complementary', Quarterly Journal of Economics, 113, 693-732.

Goldin, C. and Katz, L. F. (1999), The Return to Skill across the Twentieth Century United States, NBER Working Paper 7126.

Goldin, C. and Katz, L. F. (2001), 'The legacy of U.S. educational leadership: notes on distribution and economic growth in the $20^{\text {th }}$ century', Journal of Economic Growth, 6, 285-315.

Greene, W. (2005), 'Reconsidering heterogeneity in panel data estimators of the stochastic frontier model', Journal of Econometrics, 126, 269-303.

He, D., Zhang, W. and Shek, J. (2007), 'How efficient has been China's investment? Empirical evidence from national and provincial data', Pacific Economic Review, 12, 597-617.

Holz, C. A. (2004), 'Deconstructing China’s GDP statistics', China Economic Review, 15, 164-202.

Holz, C. A. (2006), 'New capital estimates for China', China Economic Review, 17 (2), 142-185.

Howitt, P. (2005), 'Health, human capital and economic growth: a Schumpeterian perspective', in Lopez-Casasnova, G., Rivera, B. and Currais, L. (eds), Health and Economics Growth: Findings and Policy Implications, Cambridge. MA: MIT Press, pp. 19-40.

Hseuh, T.-T. and Li, Q. (1999), China's National Income, Oxford: Westview Press.

$\mathrm{Hu}$, B. and McAleer, M. (2005), 'Estimation of Chinese agricultural production efficiencies with panel data', Mathematics and Computers in Simulation, 68, 
475-484.

Islam, N., Dai, E. and Sakamoto, H. (2006), 'Role of TFP in China’s growth', Asian Economic Journal, 20 (2), 127-159.

Jorgenson, D.W. and Z. Griliches (1967), 'The explanation of productivity change', Review of Economic Studies, 34, 249-283.

Kalirajan, K. P., Obwona, M. and Zhao, S. (1996), 'A decomposition of total factor productivity growth: the case of Chinese agricultural growth before and after reform', American Journal of Agricultural Economics, 78, 331-338.

Kumbhakar, S. C. (1990), 'Production frontiers, panel data, and time-varying technical inefficiency', Journal of Econometrics, 46 (1/2), 201-212.

Kumbhakar, S. and Lovell, K. C. A. (2000), Stochastic Frontier Analysis, New York: Cambridge University Press.

Kwack, S. Y. and Sun, L. Y. (2005), 'Economies of scale, technological progress, and the sources of economic growth: case of Korea, 1969-2000', Journal of Policy Modeling, 27, 265-283.

Kim, Sangho and Gwanho Han (2001), 'A decomposition of total factor productivity growth in Korean manufacturing industries: A stochastic frontier approach,' Journal of Productivity Analysis, 16: 269-281.

Li, K.-W. (2003), China's Capital and Productivity Measurement using Financial Resources, Discussion Paper No. 851, Economic Growth Center, Yale University, February.

Li, K.-W. (2009), 'China's total factor productivity estimates by region, investment sources and ownership', Economic Systems, 33, 213-230.

Li, K.-W., Yun, L. and Lui, G. C. S. (2009), 'Economic performance of human capital in post-reform China', The Chinese Economy, 42 (1), 40-61.

Lin, S. (2000), 'Resource allocation and economic growth in China', Economic Inquiry, 38 (3) July, 515-526.

Liu, Tung, and Li, K.-W. (2006), 'Disparity in factor contributions between coastal and inner provinces in post-reform China”, China Economic Review, 17, 449-470.

Maddison, A. and Wu, H. X. (2008), 'Measuring China's economic performance', World Economics, 9 (2), 13-44.

Organization of Economic Cooperation and Development (2001), Measuring Capital: Measurement of Capital Stocks, Consumption of Fixed Capital and Capital Services, OECD Manual, OECD Publication Service, Paris, September.

Perkins, D. H. and Rawski, T. G. (2008), 'Forecasting China's economic growth to 2025', in Brandt, L. and Rawski, T. G. (eds), China's Great Economic Transformation, Chapter 20, Cambridge: Cambridge University Press, pp. 829-887.

Population Censuses of the People's Republic of China, (1990), National Bureau of Statistics, Beijing.

Qian, X. and Smyth, R. (2006), 'Growth accounting for the Chinese provinces 1990-2000, incorporating human capital accumulation', Journal of Chinese Economic and Business Studies, 4 91), 21-37.

Rawski, T. G. and Xiao, W. (2001), 'Roundtable on Chinese economic statistics', China Economic Review, 12, 223-251.

Sharma S. C., Sylwester, K., and Margono, H. (2007), 'Decomposition of the total factor productivity growth in U.S. states', Quarterly Review of Economics and Finance, 47, 
215-241.

Solow, R. M., (1957), 'Technical change and the aggregate production function', Review of Economics and Statistics, 39 (3), 312-320.

Tabulation of the 2000 Population Census of the People's Republic of China, (2000), National Bureau of Statistics, Beijing.

Tong, C. S. P. (1999), 'Production efficiency and its spatial disparity across China's TVEs - a stochastic frontier production approach', Journal of Asian Economics, 10. 415-430.

Urel, B. and Zebregs, H. (2009), 'The dynamics of provincial growth in China: a nonparametric approach', IMF Staff Papers, 56 (2), 239-262.

Wang, Y., and Yao, Y. (2003), 'Sources of China's economic growth 1952-1999: incorporating human capital accumulation', China Economic Review, 14, 32-52.

Woo, W. T. (2002), 'Geography, economic policy and regional development in China', Asian Economics Papers, 1 (1), 146-197.

Woo, W. T. (2006), What are the High-Probability Challenges to Continued High Growth in China?, Reframing China Policy Debate Series, Carnegie Endowment for International Peace, Washington DC.

Wu, H. X. (2000), 'China's GDP level and growth performance: alternative estimates and the implications', Review of Income and Wealth, 46 (4), 475-499.

Wu, H. X. (2007), 'The Chinese GDP growth rate puzzle: how fast had the Chinese economy grown?', Asian Economic Papers, 6 (1), 1-23.

Wu, Y. (1995), 'Productivity growth, technological progress and technical efficiency change in China: a three-sector analysis', Journal of Comparative Economics, 21, 207-229.

Wu, Y. (2000), 'Is China's economic growth sustainable? A productivity analysis', China Economic Review, 11, 278-296.

Wu, Y. (2003), 'Has productivity contributed to China's growth?', Pacific Economic Review, 8 (1), 15-30.

Young, A. (2000), 'The razor's edge: distortions and incremental reform in the People's Republic of China', Quarterly Journal of Economics, 115 November, 1091-1135.

Young, A. (2003), 'Gold into base metals: productivity growth in the People's Republic of China during the reform period', Journal of Political Economy, 116 December, $1220-1261$.

Zhang, Jun (2003), 'Investment, investment efficiency, and economic growth in China', Journal of Asian Economics, 14, 713-734. 
Table 1 Maximum Likelihood Estimates of the Stochastic Frontier Production (1985-2006)

\begin{tabular}{|c|c|c|c|c|}
\hline & (1) & (2) & (3) & (4) \\
\hline $\ln K$ & $0.417 * * *$ & $0.468 * * *$ & 0.162 & $-0.181 *$ \\
\hline & $(0.002)$ & $(0.026)$ & $(0.142)$ & $(0.104)$ \\
\hline $\operatorname{lnL}$ & $\begin{array}{l}0.446 * * * \\
(0.023)\end{array}$ & $\begin{array}{l}0.415^{* * *} \\
(0.025)\end{array}$ & $\begin{array}{l}1.401 * * * \\
(0.204)\end{array}$ & $\begin{array}{l}1.509 * * * \\
(0.183)\end{array}$ \\
\hline LnH & $\begin{array}{l}0.194 * * * \\
(0.037)\end{array}$ & $\begin{array}{l}0.204 * * * \\
(0.037)\end{array}$ & $\begin{array}{l}0.508 * * \\
(0.238)\end{array}$ & $\begin{array}{l}0.542 * * \\
(0.246)\end{array}$ \\
\hline $\ln K^{*} \ln K$ & - & - & $\begin{array}{l}-0.003 \\
(0.011)\end{array}$ & $\begin{array}{l}0.025 * * * \\
(0.009)\end{array}$ \\
\hline $\ln L^{*} \ln L$ & $\begin{array}{l}- \\
-\end{array}$ & $\begin{array}{l}- \\
-\end{array}$ & $\begin{array}{l}0.097 * * * \\
(0.018)\end{array}$ & $\begin{array}{l}0.181 * * * \\
(0.031)\end{array}$ \\
\hline $\ln \mathrm{H}^{*} \ln \mathrm{H}$ & - & - & $\begin{array}{l}-0.219 * * * \\
(0.077)\end{array}$ & $\begin{array}{l}-0.326^{* * *} \\
(0.110)\end{array}$ \\
\hline $\operatorname{lnK} * \ln L$ & $\begin{array}{l}- \\
-\end{array}$ & $\begin{array}{l}- \\
-\end{array}$ & $\begin{array}{l}-0.135 * * * \\
(0.034)\end{array}$ & $\begin{array}{l}-0.105^{* * *} \\
(0.022)\end{array}$ \\
\hline $\ln K^{*} \ln H$ & $\begin{array}{l}- \\
-\end{array}$ & $\begin{array}{l}- \\
-\end{array}$ & $\begin{array}{l}0.049 \\
(0.052)\end{array}$ & $\begin{array}{l}0.134 \text { ** } \\
(0.057)\end{array}$ \\
\hline $\ln L * \ln H$ & $\begin{array}{l}- \\
-\end{array}$ & $\begin{array}{l}- \\
-\end{array}$ & $\begin{array}{l}0.088 * * \\
(0.044)\end{array}$ & $\begin{array}{l}0.157^{* *} \\
(0.075)\end{array}$ \\
\hline South region & - & $\begin{array}{l}-0.096 \\
(0.064)\end{array}$ & - & $\begin{array}{l}0.054 \\
(0.066)\end{array}$ \\
\hline Northeast region & - & $\begin{array}{l}0.157 * * * \\
(0.048)\end{array}$ & - & $\begin{array}{l}-0.130^{* * *} \\
(0.048)\end{array}$ \\
\hline West region & - & $\begin{array}{l}0.003 \\
(0.062)\end{array}$ & - & $\begin{array}{l}-0.313^{* * *} \\
(0.050)\end{array}$ \\
\hline$\mu$ & $\begin{array}{l}0.942 * * * \\
(0.123)\end{array}$ & $\begin{array}{l}0.879 * * * \\
(0.118)\end{array}$ & $\begin{array}{l}0.943 * * * \\
(0.250)\end{array}$ & $\begin{array}{l}-7.008 \\
(45.903)\end{array}$ \\
\hline$\eta$ & $\begin{array}{l}-0.024 * * * \\
(0.002)\end{array}$ & $\begin{array}{l}-0.023 * * * \\
(0.002)\end{array}$ & $\begin{array}{l}-0.030 * * * \\
(0.005)\end{array}$ & $\begin{array}{l}-0.003 \\
(0.003)\end{array}$ \\
\hline$\sigma_{u}^{2}$ & 0.156 & 0.149 & 0.508 & 2.909 \\
\hline$\sigma_{v}^{2}$ & 0.004 & 0.004 & 0.004 & 0.004 \\
\hline Log likelihood & 767.33 & 776.49 & 800.46 & 806.41 \\
\hline AIC & -1476 & -1488 & -1530 & -1536 \\
\hline BIC & -1347 & -1346 & -1374 & -1367 \\
\hline \multicolumn{5}{|c|}{ Log-Likelihood Ratio Tests $\left(\chi^{2}\right)$} \\
\hline$\beta_{i, j}=0, i, j=K, L, H$ & - & - & $61.46 * * *$ & $301.28 * * *$ \\
\hline$\delta_{R r}=0$, for all $r$ & - & $16.99 * * *$ & - & $38.51 * * *$ \\
\hline$\delta_{T t}=0$, for all $t$ & $508.97 * * *$ & $358.42 * * *$ & $274.16 * * *$ & $165.03 * * *$ \\
\hline
\end{tabular}

Notes: The estimates of $\delta_{T t}$ are not shown in the table. The numbers in parentheses are standard errors. The superscripts $*, * *$, and $* * *$ indicate that the estimated coefficient is statistically significant at the $10 \%, 5 \%$ and $1 \%$ level, respectively. 
Table 2 Output Elasticities and Cost Shares (1985-2006)

\begin{tabular}{cccccccc}
\hline Year & \multicolumn{3}{c}{ Output Elasticity } & \multicolumn{3}{c}{ Cost Share } \\
\hline & $e_{K}$ & $e_{L}$ & $e_{H}$ & $e$ & $s_{K}$ & $s_{L}$ & $s_{H}$ \\
\hline 1985 & 0.543 & 0.331 & 0.172 & 1.045 & 0.519 & 0.317 & 0.164 \\
1986 & 0.548 & 0.337 & 0.169 & 1.054 & 0.520 & 0.319 & 0.160 \\
1987 & 0.557 & 0.327 & 0.149 & 1.033 & 0.539 & 0.317 & 0.144 \\
1988 & 0.563 & 0.331 & 0.146 & 1.041 & 0.541 & 0.319 & 0.140 \\
1989 & 0.569 & 0.333 & 0.145 & 1.047 & 0.543 & 0.318 & 0.139 \\
1990 & 0.571 & 0.304 & 0.161 & 1.036 & 0.551 & 0.294 & 0.155 \\
1991 & 0.575 & 0.310 & 0.159 & 1.044 & 0.551 & 0.297 & 0.152 \\
1992 & 0.581 & 0.310 & 0.159 & 1.051 & 0.553 & 0.295 & 0.152 \\
1993 & 0.587 & 0.308 & 0.167 & 1.063 & 0.552 & 0.290 & 0.157 \\
1994 & 0.594 & 0.303 & 0.176 & 1.073 & 0.553 & 0.283 & 0.164 \\
1995 & 0.600 & 0.299 & 0.183 & 1.082 & 0.555 & 0.276 & 0.169 \\
1996 & 0.608 & 0.297 & 0.183 & 1.087 & 0.559 & 0.273 & 0.168 \\
1997 & 0.614 & 0.293 & 0.186 & 1.093 & 0.562 & 0.268 & 0.170 \\
1998 & 0.624 & 0.319 & 0.172 & 1.115 & 0.560 & 0.286 & 0.155 \\
1999 & 0.638 & 0.301 & 0.156 & 1.094 & 0.583 & 0.275 & 0.142 \\
2000 & 0.646 & 0.297 & 0.150 & 1.093 & 0.591 & 0.272 & 0.138 \\
2001 & 0.651 & 0.290 & 0.157 & 1.099 & 0.593 & 0.264 & 0.143 \\
2002 & 0.654 & 0.288 & 0.172 & 1.114 & 0.587 & 0.259 & 0.154 \\
2003 & 0.658 & 0.285 & 0.184 & 1.128 & 0.584 & 0.253 & 0.164 \\
2004 & 0.661 & 0.282 & 0.205 & 1.148 & 0.576 & 0.246 & 0.178 \\
2005 & 0.665 & 0.278 & 0.222 & 1.165 & 0.571 & 0.239 & 0.190 \\
2006 & 0.668 & 0.284 & 0.240 & 1.191 & 0.561 & 0.238 & 0.201 \\
\hline Mean & 0.614 & 0.302 & 0.174 & 1.090 & 0.563 & 0.278 & 0.159 \\
\hline
\end{tabular}


Table 3 Input Growth and Scale Effects (1986 - 2006)

\begin{tabular}{ccccccc}
\hline Year & \multicolumn{3}{c}{ Input Growth Effect } & \multicolumn{2}{c}{ Scale Effect } \\
\hline & $s_{K} \dot{K}$ & $s_{L} \dot{L}$ & $s_{H} \dot{H}$ & $\dot{\Phi}$ & $e-1$ & $(e-1) \dot{\Phi}$ \\
\hline 1986 & 4.616 & 0.896 & 0.462 & 5.974 & 0.054 & 0.321 \\
1987 & 4.794 & 0.863 & 0.457 & 6.115 & 0.033 & 0.203 \\
1988 & 5.138 & 0.822 & 0.420 & 6.379 & 0.041 & 0.260 \\
1989 & 4.469 & 0.566 & 0.307 & 5.342 & 0.047 & 0.250 \\
1990 & 4.215 & 0.778 & 0.285 & 5.277 & 0.036 & 0.188 \\
1991 & 4.359 & 0.821 & 0.390 & 5.570 & 0.044 & 0.246 \\
1992 & 5.409 & 0.520 & 0.361 & 6.290 & 0.051 & 0.319 \\
1993 & 6.458 & 0.658 & 0.272 & 7.388 & 0.063 & 0.467 \\
1994 & 6.443 & 0.398 & 0.227 & 7.069 & 0.073 & 0.519 \\
1995 & 6.335 & 0.366 & 0.273 & 6.974 & 0.082 & 0.573 \\
1996 & 5.968 & 0.375 & 0.433 & 6.776 & 0.087 & 0.591 \\
1997 & 5.696 & 0.307 & 0.324 & 6.328 & 0.093 & 0.589 \\
1998 & 5.987 & 0.029 & 0.422 & 6.437 & 0.115 & 0.743 \\
1999 & 5.653 & -1.033 & 0.524 & 5.144 & 0.094 & 0.485 \\
2000 & 5.394 & 0.092 & 0.379 & 5.865 & 0.093 & 0.546 \\
2001 & 5.469 & 0.102 & 0.132 & 5.704 & 0.099 & 0.563 \\
2002 & 5.581 & 0.548 & 0.034 & 6.163 & 0.114 & 0.705 \\
2003 & 6.059 & 0.490 & 0.115 & 6.664 & 0.128 & 0.854 \\
2004 & 6.606 & 0.609 & -0.032 & 7.183 & 0.148 & 1.065 \\
2005 & 6.676 & 0.529 & 0.067 & 7.272 & 0.165 & 1.204 \\
2006 & 6.929 & 1.114 & 0.191 & 8.235 & 0.191 & 1.575 \\
\hline Mean & 5.631 & 0.469 & 0.288 & 6.409 & 0.090 & 0.597 \\
\hline
\end{tabular}

Notes: $\dot{\Phi}$ is the growth of aggregate input, $\dot{\Phi}=s_{K} \dot{K}+s_{L} \dot{L}+s_{H} \dot{H}$. The average growth rates of physical capital, labor, and human capital over the sample period are $10 \%, 1.67 \%$, and $1.87 \%$, respectively. 
Table 4 Decomposition of Output Growth and the TFP growth (1987-2006)

\begin{tabular}{ccccccc}
\hline & $\dot{Y}$ & $\dot{\Phi}$ & Scale & $\Delta \delta_{T t}$ & $T \dot{E}$ & $T \dot{F P}$ \\
\hline 1987 & \multicolumn{1}{c}{$(1)$} & $(2)$ & $(3)$ & $(4)$ & $(5)$ & $(3)+(4)+(5)$ \\
1988 & 9.337 & 6.115 & 0.203 & 3.112 & -0.093 & 3.222 \\
1989 & 10.565 & 6.379 & 0.260 & 4.018 & -0.092 & 4.185 \\
1990 & 4.238 & 5.342 & 0.250 & -1.261 & -0.092 & -1.104 \\
1991 & 5.747 & 5.277 & 0.188 & 0.386 & -0.104 & 0.470 \\
1992 & 7.348 & 5.570 & 0.246 & 1.636 & -0.104 & 1.778 \\
1993 & 14.112 & 6.290 & 0.319 & 7.606 & -0.104 & 7.822 \\
1994 & 13.721 & 7.388 & 0.467 & 5.970 & -0.103 & 6.333 \\
1995 & 12.598 & 7.069 & 0.519 & 5.114 & -0.103 & 5.530 \\
1996 & 11.233 & 6.974 & 0.573 & 3.788 & -0.103 & 4.258 \\
1997 & 10.809 & 6.776 & 0.591 & 3.545 & -0.103 & 4.033 \\
1998 & 10.016 & 6.328 & 0.589 & 3.201 & -0.102 & 3.688 \\
1999 & 8.698 & 6.437 & 0.743 & 1.608 & -0.090 & 2.261 \\
2000 & 7.447 & 5.144 & 0.485 & 1.908 & -0.090 & 2.303 \\
2001 & 9.046 & 5.865 & 0.546 & 2.725 & -0.089 & 3.182 \\
2002 & 9.293 & 5.704 & 0.563 & 3.115 & -0.089 & 3.589 \\
2003 & 10.130 & 6.163 & 0.705 & 3.351 & -0.089 & 3.967 \\
2004 & 11.345 & 6.664 & 0.854 & 3.915 & -0.089 & 4.681 \\
2005 & 12.428 & 7.183 & 1.065 & 4.268 & -0.088 & 5.245 \\
2006 & 12.124 & 7.272 & 1.204 & 3.736 & -0.088 & 4.852 \\
\hline Average & 12.825 & 8.235 & 1.575 & 3.103 & -0.088 & 4.591 \\
\hline
\end{tabular}

